\title{
Effect of Different Pre Sowing Treatments on Seed Germination and Seedling Growth of Walnut (Juglans regia L.)
}

\author{
Priya Negi $^{1 *}$, B.P. Nautiyal ${ }^{2}$, Nidhika Thakur ${ }^{1}$, Manju Negi ${ }^{1}$ and Vinita Kumari Meena ${ }^{3}$ \\ ${ }^{1}$ Department of Fruit Science, VCSG, UUHF, Bharsar, Pauri Garhwal, U.K, India \\ ${ }^{2}$ Department of MAP, VCSG, UUHF, Bharsar, Pauri Garhwal, U.K, India \\ ${ }^{3}$ Department of Horticulture, R.C.A., MPUA\&T, Udaipur, Rajasthan, India \\ *Corresponding author
}

\begin{tabular}{|c|c|}
\hline & BST RACT \\
\hline $\begin{array}{l}\text { K e y w o r d s } \\
\text { walnut, } \\
\text { Gibberellic acid, } \\
\text { Stratification, } \\
\text { Cracking, } \\
\text { Hotwater. }\end{array}$ & \multirow{3}{*}{$\begin{array}{l}\text { A systematic study was undertaken to determine the best pre sowing treatments for seed } \\
\text { germination and seedling growth of walnut. The germination and seedling growth of } \\
\text { walnut improved with combine application of all pre sowing treatments. Cracking + } \\
\text { gibberellic acid @ } 500 \mathrm{ppm}+\text { stratification for } 30 \text { days showed highest germination } \\
\text { percentage and early germination was obtained under the treatment combination of } \\
\text { cracking, gibberellic acid @ } 750 \mathrm{ppm} \text { with stratification for } 30 \text { days. Highest shoot height, } \\
\text { shoot diameter, number of leaves per plant, root length, root area, shoot fresh weight, root } \\
\text { fresh weight, total fresh weight and survival percentage were recorded with hot water + } \\
\text { gibberellic acid @ } 500 \mathrm{ppm}+\text { stratification for } 30 \text { days. Thus, the results of present } \\
\text { investigation reveal that it is combination of different pre sowing treatments was found } \\
\text { effective in improving the germination and growth of walnut seedlings as compared to the } \\
\text { control. }\end{array}$} \\
\hline Article Info & \\
\hline $\begin{array}{l}\text { Accepted: } \\
\text { 29 June } 2017 \\
\text { Available Online: } \\
\text { 10 July } 2017\end{array}$ & \\
\hline
\end{tabular}

\section{Introduction}

Walnut (Juglans regia L.) is an important temperate nut crop with delicious kernel. It belongs to the family Juglandaceae and genus Juglans. The genus Juglans has 21 species of which Juglans regia is the most important. Seed dormancy is a barrier to walnut seed germination.

Seed dormancy has been attributed to one or more factors (Stockes, 1965) i.e. hard and impermeable seed coat, immaturity of embryo, after ripening in dry storage, inhibitors and germination stimulators and light sensitivity of seeds. In case of walnut the seed dormancy has been correlated with physiological dormancy that is controlled by seed coat and embryo dormancy. Seed germination is a complex process that started with the absorption of water and after a short pause; the enzyme is activated (Matilla and Matilla-Vazquez, 2008).

Many practices are most commonly followed to break the dormancy in walnut seeds, in order to improve or stimulate germination i.e. scarification, stratification and gibberellic acid.

The aim of this study was to test different pre sowing treatments in an attempt to improve overall germination percentage and early germination of walnut seed. 


\section{Material and Methods}

Fully mature seeds were collected from the nearby places of College of Horticulture, VCSG, UUHF, Bharsar during 2015-16. Seeds were selected, washed, float-checked, and air dried. Selected seeds were subjected to different pre sowing treatments such as cracking, hot water, gibberellic acid at three different concentration $(500 \mathrm{ppm}, 750 \mathrm{ppm}$ and $1000 \mathrm{ppm}$ ), stratification for 30 days and their combinations such as three different concentration $(500 \mathrm{ppm}, 750 \mathrm{ppm}$ and 1000 ppm) of gibberellic acid with cracking and hot water, combination of cracking and hot water with stratification for 30 days and combination of cracking and hot water with three different concentration (500 ppm, 750 ppm and $1000 \mathrm{ppm}$ ) of gibberellic acid under stratification period of 30 days and sowed in Randomized Complete Block Design with three replications at the spacing $(30 \times 10)$ $\mathrm{cm}^{2}$ in poly house.

\section{Results and Discussion}

\section{Seed germination}

The combine application of different pre sowing treatments resulted in minimum days taken for germination and maximum germination. Seeds of walnut showed early germination (12.67 days) and best germination $(75.88 \%)$ when combination of cracking with $\mathrm{GA}_{3} @ 750$ ppm stratification for 30 days and combination of cracking with $\mathrm{GA}_{3} @ 500$ ppm for 30 days stratification were used respectively as compared to control and single treatments, the maximum germination might be due to the fact that $\mathrm{GA}_{3}$ involved in the activation of cytological enzymes which stimulates $\alpha-$ amylase enzyme that converts insoluble starch into soluble sugars (Babu et al., 2010) and early germination might be due to the fact that, $\mathrm{GA}_{3}$ plays an important role in two stages of germination one at initial enzyme induction and other in activation of reserve food mobilizing system which help in enhancement of germination (Jha et al., 1997). In the present studies, it has been observed that gibberellic acid was required in relatively lower concentration with stratification and scarification for the maximum germination. The inability of walnut seeds to germinate may be due to the hard seed coat. As the scarification treatment given to the seed helped in uptake of water, growth hormones and air which was required for seed germination (Çetinbaş et al., 2006; Conner, 2008 and Al-Absi, 2010). Prechilling stratification had a significant effect on seed dormancy. It can be attributed that at low temperature more oxygen dissolves in water and therefore more oxygen is available for embryo (Young and Young, 1992).

\section{Shoot growth}

The maximum shoot height $(37.35 \mathrm{~cm})$, shoot diameter $(3.97 \mathrm{~mm})$ number of leaves $(40.00)$ were noticed under combination of hot water with $\mathrm{GA}_{3} @ 500$ ppm under 30 days stratification period. It might be due to the effect of $\mathrm{GA}_{3}$ and stratification on enhancing growth due to the solubility of fats and sugars caused by stratification plus the increase in gibberellin synthesis. In addition, the improving effect of $\mathrm{GA}_{3}$ and stratification on seed germination might have reflected on enhancing the shoot parameters. These results are in agreement with Dahkaei (2009) on Danae racemosa, Rawat et al., (2010) on Punica granatum and Hassan and Fetouh (2014) on seeds of Magnolia grandiflora. Seedling which was raised from this treatment combination attained more height which suggests that as the height of seedlings increased, there was a simultaneous increase in the number of leaves. Similar observations were recorded by Mathur (1964) in peach and apricot seedlings. The $\mathrm{GA}_{3}$ hormone increases cell size by stimulating the cell wall to release and transmit its calcium into the cytoplasm 
that provides a condition for absorption of water and cell growth and in stratification, endosperm is disrupted permitting embryo growth. On the other hand, low temperatures stimulate the breakdown of proteins into soluble nitrogenous compounds and formation of the amino acids glycine and argentine, which are beneficial for embryo growth (Baskin and Baskin, 2001 and Razavi et al., 2009)

\section{Root growth}

The highest root length $(27.52 \mathrm{~cm})$ as well as root area $\left(19.62 \mathrm{~cm}^{2}\right)$ was recorded with the application of hot water + gibberellic acid @ $500 \mathrm{ppm}+$ stratification for 30 days. It might be due to the reason that the shoot growth resulted in production of photosynthatates which were translocated through phloem to the root zone and was responsible for increase in root length. Pravin et al., (2015) who reported maximum root length and root area of walnut with combination of gibberellic acid and stratification, the effect of $\mathrm{GA}_{3}$ and stratification on root parameters followed the same trend as on the shoots. The positive effect of $\mathrm{GA}_{3}$ and stratification on root parameters might be explained through the role of $\mathrm{GA}_{3}$ and stratification in enhancing gibberellin synthesis which also leads in increase the growth and root branching and overall increase in root fresh weight (Penfield et al., 2005).

\section{Shoot and root fresh weight}

The maximum shoot fresh weight $(12.47 \mathrm{~g})$, root fresh weight $(12.10 \mathrm{~g})$ and total fresh weight $(24.54 \mathrm{~g})$ were recorded with the combined application of hot water, gibberellic acid @ 500 ppm and stratification for 30 days. This promotion could be explained through the role of stratification in enhancing gibberellin synthesis which also leads to increase in the growth and root branching and overall increased roots fresh weight. The production of maximum shoot, root height, diameter and maximum number of leaves which suggests that as the all the growth parameters of shoot and root of seedlings increased, there was a simultaneous increase in the shoot and root fresh weight. Similar observations were recorded and confirmed by Pawar et al., (2010) in Jatropa, Farhoudi et al., (2015) in Echinacea purpurea and Parvin et al., (2015) in black walnut.

\section{Survival percentage}

The maximum survival percentage $(93.24 \%)$ was recorded with combination application of hot water + gibberellic acid @ 500 ppm + stratification for 30 days. It might be because stratification increased the early germination which resulted into longest radicle, which helps in early establishment of new seedling to produce maximum food material with the helped in photosynthesis that resulted into the maximum survival of seedlings.

The results are in conformity with the findings of Wani (2014) who observed increase in the survival percentage with the application of gibberellic acid @ 500 ppm for 40 hours. It might be as $\mathrm{GA}_{3}$ favors the increased enzymatic activity that leads to the favorable environment for the seed germination as well as the growth of the radicle and plumule leading to better growth and survival of seedlings.

In conclusion, the results obtained in the present studies showed that among different pre sowing treatments, the best results in terms of shoot height, shoot diameter, number of leaves per plant, root length, root area, shoot fresh weight, root fresh weight, total fresh weight and survival percentage were obtained with hot water + gibberellic acid @ $500 \mathrm{ppm}+$ stratification for 30 days (Table 1). 
Table.1 Effect of different pre sowing treatments on seed germination and seedling growth of walnut

\begin{tabular}{|c|c|c|c|c|c|c|c|c|c|c|c|c|c|}
\hline Treatments & $\begin{array}{l}\text { Days taken } \\
\text { for initial } \\
\text { germination }\end{array}$ & $\begin{array}{l}\text { Germination } \\
\text { percentage }\end{array}$ & Shoot height & $\begin{array}{l}\text { Shoot } \\
\text { diameter }\end{array}$ & $\begin{array}{l}\begin{array}{l}\text { Number of } \\
\text { branches/ }\end{array} \\
\text { plant }\end{array}$ & $\begin{array}{l}\text { Number of } \\
\text { leaves/plant }\end{array}$ & $\begin{array}{l}\text { Root } \\
\text { length }\end{array}$ & $\begin{array}{l}\text { Root } \\
\text { diameter }\end{array}$ & Root area & $\begin{array}{l}\text { Shoot fresh } \\
\text { weight }\end{array}$ & $\begin{array}{l}\text { Root fresh } \\
\text { weight }\end{array}$ & $\begin{array}{l}\text { Total fresh } \\
\text { weight }\end{array}$ & $\begin{array}{l}\text { Survival } \\
\text { percentage }\end{array}$ \\
\hline$T_{1}$ (Cracking) & $59.33 \pm 0.67$ & $49.89(7.13 \pm 0.05)$ & $20.07 \pm 0.88$ & $2.06 \pm 0.30$ & $5.17 \pm 0.60$ & $20.00 \pm 0.00$ & $15.02 \pm 0.73$ & $3.14 \pm 0.42$ & $12.40 \pm 0.29$ & $5.40 \pm 0.40$ & $5.33 \pm 0.83$ & $10.73 \pm 0.72$ & $69.87(8.42 \pm 0.04)$ \\
\hline$T_{2}$ (Hot water) & $56.33 \pm 0.88$ & $47(6.93 \pm 0.13)$ & $22.21 \pm 0.67$ & $2.52 \pm 0.05$ & $5.83 \pm 0.60$ & $25.61 \pm 1.75$ & $13.56 \pm 0.95$ & $3.36 \pm 0.18$ & $11.74 \pm 0.37$ & $5.71 \pm 0.11$ & $4.22 \pm 0.38$ & $9.93 \pm 0.49$ & $72.56(8.58 \pm 0.08)$ \\
\hline$T_{3}($ Cracking+GA 3 @500ppm) & $25.67 \pm 1.20$ & $53.54(8.07 \pm 0.06)$ & $26.75 \pm 0.99$ & $3.08 \pm 0.32$ & $6.67 \pm 0.44$ & $31.40 \pm 4.20$ & $19.71 \pm 0.41$ & $5.45 \pm 0.21$ & $14.71 \pm 0.14$ & $7.17 \pm 1.33$ & $6.67 \pm 0.78$ & $13.84 \pm 1.41$ & $86.91(9.38 \pm 0.01)$ \\
\hline$T_{4}($ Cracking+GA $3 @ 750 p p m)$ & $25.33 \pm 1.33$ & $64.07(7.87 \pm 0.05)$ & $28.92 \pm 0.71$ & $3.11 \pm 0.17$ & $7.50 \pm 0.58$ & $34.01 \pm 1.03$ & $21.26 \pm 0.51$ & $5.53 \pm 0.12$ & $15.41 \pm 0.47$ & $8.58 \pm 0.17$ & $7.40 \pm 0.70$ & $15.98 \pm 0.81$ & $78.62(8.92 \pm 0.12)$ \\
\hline$T_{5}($ Cracking+GA 3 @ 1000ppm) & $26.00 \pm 1.15$ & $60.99(7.38 \pm 0.11)$ & $25.00 \pm 0.86$ & $2.43 \pm 0.05$ & $6.67 \pm 0.67$ & $31.48 \pm 1.48$ & $17.70 \pm 0.45$ & $4.54 \pm 0.10$ & $14.19 \pm 0.82$ & $6.50 \pm 0.80$ & $6.72 \pm 0.75$ & $13.22 \pm 0.35$ & $73.85(8.65 \pm 0.05)$ \\
\hline $\mathrm{T}_{6}($ HotWater+GA 3 @500ppm) & $19.67 \pm 0.67$ & $60.71(7.85 \pm 0.07)$ & $27.18 \pm 1.73$ & $3.30 \pm 0.15$ & $6.83 \pm 0.73$ & $30.97 \pm 0.73$ & $21.63 \pm 1.07$ & $4.82 \pm 0.11$ & $16.78 \pm 0.82$ & $7.77 \pm 0.47$ & $7.39 \pm 0.77$ & $16.59 \pm 1.22$ & $87.42(9.40 \pm 0.11)$ \\
\hline $\mathbf{T}_{7}($ HotWater+GA $@$ @750ppm) & $19.00 \pm 1.15$ & $55.63(7.52 \pm 0.16)$ & $30.38 \pm 1.18$ & $3.45 \pm 0.00$ & $7.33 \pm 0.60$ & $35.24 \pm 1.95$ & $23.65 \pm 0.75$ & $5.75 \pm 0.83$ & $16.03 \pm 0.20$ & $9.19 \pm 0.30$ & $7.18 \pm 0.09$ & $14.95 \pm 0.21$ & $85.26(9.29 \pm 0.04)$ \\
\hline 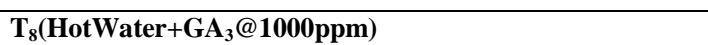 & $19.33 \pm 0.33$ & $53.72(7.39 \pm 0.29)$ & $25.12 \pm 0.39$ & $3.19 \pm 0.14$ & $6.17 \pm 1.30$ & $30.87 \pm 3.66$ & $18.48 \pm 1.52$ & $5.05 \pm 0.42$ & $14.48 \pm 0.76$ & $6.74 \pm 0.25$ & $6.50 \pm 0.49$ & $13.23 \pm 0.28$ & $83.18(9.17 \pm 0.10)$ \\
\hline$T_{9}$ (Cracking + stratification for 30 days) & $19.00 \pm 0.58$ & $52.05(7.28 \pm 0.09)$ & $26.35 \pm 1.57$ & $3.12 \pm 0.23$ & $6.00 \pm 0.76$ & $30.07 \pm 2.37$ & $17.61 \pm 0.46$ & $3.64 \pm 0.25$ & $14.39 \pm 0.14$ & $6.93 \pm 0.53$ & $6.09 \pm 0.49$ & $13.02 \pm 0.75$ & $82.78(9.15 \pm 0.08)$ \\
\hline$T_{10}$ (Hot Water + stratification for 30 days) & $18.00 \pm 1.53$ & $50.15(7.15 \pm 0.04)$ & $29.03 \pm 0.86$ & $3.05 \pm 0.35$ & $6.23 \pm 0.43$ & $25.99 \pm 2.06$ & $20.23 \pm 0.42$ & $3.43 \pm 0.49$ & $13.70 \pm 0.44$ & $7.13 \pm 0.32$ & $6.33 \pm 0.65$ & $13.47 \pm 0.80$ & $85.62(9.31 \pm 0.04)$ \\
\hline$T_{11}\left(\right.$ Cracking+GA ${ }_{3} @ 500 p p m+$ Stratification for 30 days $)$ & $14.33 \pm 0.33$ & $75.88(8.77 \pm 0.11)$ & $34.79 \pm 0.35$ & $3.48 \pm 0.19$ & $7.57 \pm 0.07$ & $36.33 \pm 0.90$ & $25.25 \pm 0.37$ & $3.42 \pm 0.65$ & $18.65 \pm 0.12$ & $11.89 \pm 0.29$ & $10.75 \pm 0.56$ & $22.00 \pm 0.70$ & $91.60(9.62 \pm 0.14)$ \\
\hline$T_{12}($ Cracking+GA 3 @750ppm+ Stratification for 30 days $)$ & $12.67 \pm 0.33$ & $73.05(8.60 \pm 0.04)$ & $34.73 \pm 0.52$ & $3.58 \pm 0.16$ & $7.33 \pm 0.60$ & $35.47 \pm 2.24$ & $25.04 \pm 0.45$ & $3.27 \pm 0.21$ & $17.94 \pm 0.53$ & $10.51 \pm 0.60$ & $7.28 \pm 0.29$ & $17.79 \pm 0.81$ & $90.33(9.55 \pm 0.13)$ \\
\hline$T_{13}($ Cracking+GA $3 @ 1000 p p m+$ Stratification for 30 days $)$ & $14.33 \pm 0.33$ & $71.63(8.52 \pm 0.04)$ & $30.50 \pm 0.91$ & $3.09 \pm 0.07$ & $6.50 \pm 0.58$ & $30.74 \pm 0.74$ & $23.35 \pm 1.52$ & $3.37 \pm 0.55$ & $17.57 \pm 0.54$ & $9.34 \pm 0.41$ & $6.11 \pm 0.24$ & $15.45 \pm 0.19$ & $87.30(9.40 \pm 0.10)$ \\
\hline$T_{14}\left(\right.$ HotWater+GA $+G_{3} @ 500 p p m+$ Stratification for 30 days $)$ & $13.33 \pm 0.33$ & $74.46(8.67 \pm 0.07)$ & $37.35 \pm 0.34$ & $3.97 \pm 0.31$ & $8.00 \pm 0.00$ & $40.00 \pm 0.00$ & $27.52 \pm 0.60$ & $4.59 \pm 0.10$ & $19.62 \pm 0.32$ & $12.47 \pm 0.04$ & $12.10 \pm 0.19$ & $24.57 \pm 0.23$ & $93.24(9.71 \pm 0.05)$ \\
\hline$T_{15}($ HotWater+GA $@$ @750ppm+ Stratification for 30 days $)$ & $14.00 \pm 0.58$ & $72.34(8.56 \pm 0.07)$ & $35.28 \pm 0.22$ & $3.30 \pm 0.07$ & $7.17 \pm 0.00$ & $35.67 \pm 0.67$ & $24.53 \pm 1.15$ & $4.16 \pm 0.53$ & $18.47 \pm 0.40$ & $11.25 \pm 0.28$ & $7.87 \pm 0.86$ & $19.76 \pm 1.09$ & $91.19(9.60 \pm 0.09)$ \\
\hline$T_{16}($ HotWater+GA $@ 1000 p p m+$ Stratification for 30 days $)$ & $14.67 \pm 0.33$ & $71.63(8.52 \pm 0.04)$ & $31.08 \pm 0.85$ & $3.24 \pm 0.16$ & $7.00 \pm 0.88$ & $32.71 \pm 1.40$ & $23.33 \pm 0.63$ & $4.56 \pm 0.54$ & $17.67 \pm 0.67$ & $9.25 \pm 0.25$ & $7.12 \pm 0.11$ & $16.37 \pm 0.33$ & $88.11(9.43 \pm 0.09)$ \\
\hline$T_{17}$ (Control) & $76.67 \pm 9.26$ & $45.66(6.90 \pm 0.29)$ & $18.58 \pm 0.88$ & $2.17 \pm 0.34$ & $5.00 \pm 0.58$ & $23.33 \pm 4.41$ & $14.32 \pm 0.84$ & $2.53 \pm 0.30$ & $12.04 \pm 0.42$ & $5.33 \pm 0.55$ & $4.54 \pm 0.13$ & $9.87 \pm 0.46$ & $67.33(8.26 \pm 0.23)$ \\
\hline$\pm \mathrm{SE}(\mathrm{m})$ & 3.38 & $1.89(0.18)$ & 1.28 & 0.31 & 0.98 & 3.10 & 1.09 & 0.57 & 0.58 & 0.73 & 0.78 & 1.00 & $2.43(0.13)$ \\
\hline $\mathbf{C D}_{0.05}$ & 6.88 & $3.79(0.37)$ & 2.61 & 0.63 & NS & 6.31 & 1.092 .23 & 1.16 & 1.18 & 1.48 & 1.59 & 2.04 & $4.96(0.28)$ \\
\hline
\end{tabular}


The maximum germination percentage was recorded with cracking + gibberellic acid @ $500 \mathrm{ppm}+$ stratification for 30 days while the minimum days taken for germination were recorded with cracking + gibberellic acid @ $750 \mathrm{ppm}+$ stratification for 30 days. Hence, it is concluded that the combination of different pre sowing treatments was found effective in improving the germination and growth of walnut seedlings and the best treatment was $\mathrm{T}_{14}$ (hot water + gibberellic acid @ 500 ppm + stratification for 30 days) which was highly effective in improving the overall growth of walnut seedlings.

\section{References}

Al-Absi, K.M. 2010. The effects of different pre-sowing seed treatments on breaking the dormancy of Mahaleb cherries, (Prunus mahaleb L.) seeds. Seed Sci. Technol., 38: 332-340.

Anburani, A., and Shakila, A. 2010. Influence of seed treatment on the enhancement of germination and seedling vigor of papaya. Acta Horticulturae, 851: 29598

Babu, K.D., Patel, R.K., Singh, A., Yadav, D.S., De, L.C., and Deka, B.C. 2010. Seed germination, seedling growth and vigour of papaya under North east Indian condition. Acta Horticulturae, 851: 299-306.

Barche, S. Kirad, K.S. and Singh, D.B. 2010. Response of seed treatment on germination, growth, survivability and economics of different cultivars of papaya. Acta Horticulturae, 851: 279284.

Baskin, C.C. and Baskin, J. 2001. Seeds: Ecology, Biogeography and Evolution of Dormancy and Germination. San Diego, Academic Press.

Çetinbaş, M. and Koyuncu, F. 2006. Improving germination of Prunus avium L. seeds by gibberellic acid, potassium nitrate and thiourea. Hortsci., (Prague) 33(3): 119-123.

Conner, P.J. 2008. Effects of stratification, germination, temperature and pretreatment with gibberellic acid and hydrogen peroxide on germination of 'Fry' muscadine (Vitis rotundifolia) seed. Horticulture Sci., 43: 853-856.

Dahkaei, M.N.P. 2009. Effect of Gibberellic acid, temperature and cold moist stratification on seed germination of Danae racemosa. Acta Horticulturae, 813: 445-452.

Farhoudi, R., Modhej, A. and Jamshidi, A.R. 2015. Echinacea purpurea seed pretreatment to improve germination. Res. J. Fishries and Hydrobiol., 10(9): 58-61.

Fetouh, M.I. and Hassan, F.A. 2014. Seed germination criteria and seedling characteristics of Magnolia grandiflora L. trees after cold stratification treatments. Int. J. Curr. Microbiol. Appl. Sci., 3(3): 235-241.

Jha, B.N., Kumar, V., Singh, R.P. Kumari, R. and Sinha, M. 1997. Dormancy in groundnut Standardization of procedure of breaking. J. Appl. Biol., 7: 23-25.

Mathur, D.D., Couvilon, G.A., Vines, H.M. and Hendershott, C.H. 1971. Stratification effects on endogenous gibberellic acid in peach seeds. Hortsci., 6: 538.

Matilla, A.J. and Matilla-Vazquez, M.A. 2008. Involvement of ethylene in seed physiology. Plant Sci., 175: 87-97.

Parvin, P. Khezri, M. Tavasolian, I. and Hosseini, H. 2015. The Effect of Gibberellic Acid and Chilling Stratification on Seed Germination of Eastern Black Walnut (Juglans nigra L.) J. Nuts, 6(1): 67-76.

Pawar, V.B., Gore, R.V., Patil, V.K. and Narsude, P.B. 2010. Effect of gibberellic acid on seed germination 
and growth of Jatropha curcasL. The Asian J. Horticulture, 5(2): 311-313.

Penfield, S. Josse, E.M. Kannangara, R. Gilday, A., D. Halliday,K., J. and Graham, I.A. 2005. Cold and light control seed germination through the bHLH transcription factor spatula. Curr. Biol., 15: 1998-2006.

Powell, L.E. 1987. Hormonal aspects of bud and seed dormancy in temperate-zone woody plants. Hortsci., 22: 845-850.

Pratibha, C. Teja, T. and Krishna, P.M. 2015. Effect of Chemical Treatments on the Germination and Subsequent Seedlings Growth of Papaya (Carica papaya L.) Seeds cv. Pusa Nanha. J. Agri. Engi. Food Technol., 2(3): 189-191.

Rawat, J.M.S., Tomar, Y.K. and Rawat, V. 2010. Effect of stratification on seed germination and seedling performance of wild pomegranate. J. American Sci.,
6(5): 97-99.

Razavi, S.M. and Hajiboland, R. 2009. Dormancy breaking and germination of Prangos ferulaceae seeds. Eur. Asian J. BioSci., 3(11): 78-83.

Stokes, P. 1965. Temperature and seed dormancy. In: Ruhland W. (Eds.), Encyclopedia of Plan Physiology, 15/2. Springer-Verlag, Berlin, Heidelberg and New York, Pp. 746-803.

Wani, R.A., Malik, T.H., Malik, A.R., Baba, J.A. and Dar, N.A. 2014. Studies on apple seed germination and survival of seedlings as affected by gibberellic acid under cold arid conditions. Int. J. Scientific \& Technol. Res., 3(3): 210216.

Young, J.A. and Young, C.G. 1992. Seeds of Woody Plants in North America. Portland, Oregon, Dioscorides Press.

\section{How to cite this article:}

Priya Negi, B.P. Nautiyal, Nidhika Thakur, Manju Negi and Vinita Kumari Meena. 2017. Effect of Different Pre Sowing Treatments on Seed Germination and Seedling Growth of Walnut (Juglans regia L.). Int.J.Curr.Microbiol.App.Sci. 6(7): 3844-3849. doi: https://doi.org/10.20546/ijcmas.2017.607.396 